\title{
Retalhos de vida
}

Maria Clara Maciel de Araújo Ribeiro ${ }^{1}$

O sol cutucou João. É hora. O sono se dissipa, dilui como que por solvente quando aquele primeiro raio de sol perfura a janela. Os olhos fixos na paisagem como que a procura de um sinal. Lá fora umas folhagens secas, uma cerca velha que separa sua casa da ruela e uma antiga cisterna desativada. Os olhos insistem. Talvez haja um sinal, vamos lá, me mandem um sinal, estou aguardando. Um momento de reflexão e a certeza de que realmente se esqueceram dele. Talvez seja hora. João enche o peito de ar, alargando aquela caixa esqueletosa que já havia sido mais cheiazinha nos tempos de juventude, e sopra tudo de uma vez só, fazendo voar as folhas de papel por sobre a cama desarrumada.

São papéis inúteis, pensa ele. Alguns rabiscos que vem guardando desde a época da adolescência. Alguns pensamentos desconexos, algumas sobras de amarguras antigas, uns pinguinhos de poucas e espaças alegrias e uma pilha de sonhos acumulados. João guardava aquilo para seus filhos, se eles viessem a ser concebidos um dia. Pensava que ali estava a essência de seu ser. Sonhava em organizar tudo aquilo em um livro e quem sabe um dia ser lido por muitos. Mas agora, já quase na chamada terceira idade, e ainda sem ninguém a quem transferir o espólio de sua miséria e as migalhas de seus sonhos, João pensa que bem poderia acabar logo com aquele resto minguado de

1 Doutoranda em Estudos Linguísticos pela Universidade Federal de Minas Gerais (UFMG).Contato: mclaramaciel@hotmail.com 
esperança e se ver livre, por fim, da obrigação de ser feliz. Se aceitássemos a mediocridade da vida, talvez ela fosse mais fácil.

Dormiu sobre os papeis na noite passada. E acordou ainda com um deles entre os dedos. Os olhos vagueiam a paisagem e nada ainda de nenhuma porcaria de sinal, pensa João. É isso, acabo com tudo e fim de papo. João arrasta-se pesadamente da cama, pega a bacia de alumínio, os papéis, a cachaça e os fósforos e prepara-se para o rito de expurgação através da cremação que viria. Não teve coragem de picar os papéis; coloca-os cuidadosamente sobre a bacia. Não dá pra entender o rumo que a vida toma; demora-se para compreender o jogo da vida. A primeira vida deveria ser provinha, rascunho, aprendizado para a segunda, que seria definitiva, pra valer. De que é que adianta pensar isso agora? Nada aconteceu como deveria ser. A vida foi percorrer uma estrada que deu em lugar nenhum, conduzida por um bobo da corte. E o bobo sou eu.

João dormiu com uma folha de papel entre os dedos, e ela ainda continua por lá. Será difícil soltá-la. Em suas linhas pode-se ler um rapaz apaixonado, que desistiu da namorada por um cargo de operário na cidade. Lê-se também as aventuras amorosas de um sertanejo que não sabia que na cidade o amor precisava ser pago. Um pedaço triste de um aprendizado forçado. E do outro lado do papel pode ser vista uma lista de sonhos, numerados pela ordem de grandeza: casar com Rosinha, ser promovido na fábrica, levantar um barracão, largar a bebida, deixar as vadias, manter as unhas cortadas...ser feliz.

Melhor seria não ter lido este trecho novamente, tê-lo queimado de vez. João fica imóvel diante dos artefatos de destruição, observando-os calado: a cachaça, os fósforos, a bacia e os papéis. É neste momento que pensa que seus sonhos foram a melhor parte de si. Eles não mereciam ser punidos. Os papéis não tem culpa de nada, jamais poderiam ser punidos com a destruição. João se dirige ao terreiro, cobre seu próprio corpo de cachaça e ateia fogo em si mesmo, bem distante da bacia com sua pilha de sonhos. 


\section{Noites vazias}

Se tivesse mais idade, certamente teria calculado os riscos, as perdas e os ganhos antes de se envolver. Mas é assim que a vida funciona: o impensado e o inesperado fazem parte das leis naturais de ajuste ao mundo assim como o raciocínio lógico e a razão. E as atitudes de uma e de outra época encaixam-se e justificam-se algum dia na vida. Disso também ela só teria consciência com o passar do tempo, pois, naquele tempo, bastava a sombra da mais abstrata intuição para fazê-la prosseguir ou recuar. Impulso, sempre o impulso. E um impulso tão primitivo que beirava a loucura.

Aquele comportamento não era estranho a ninguém. A ninguém que lhe conhecia. Mas quando aquele moço de barbicha hospedou-se na casa de seus pais, sancionou-se a mais nova lei da família: ninguém pisca, mexe, respira de forma estranha perto desse moço. O filho do meu chefe precisa sair bem impressionado. Dito e feito. É claro. Seria um exercício interessante: nada é mais simples que trancafiar por alguns dias a loucura intima rotineira e comportar-se de maneira imperceptível, comum, não é? Não sei bem se é, mas para ela, jamais seria. Afastar-se dos lugares preenchidos por ele foi a única solução encontrada.

$\mathrm{E}$ foi de tanta esquiva que brotou aquela insana curiosidade: "será quem é? Como é? O que cheira? O que come? O que veste? O que pensa? A voz é rouca, sensualmente bem impostada; sei que deixa a barba por fazer. E os olhos? Que olhos tem ele?" Pare de escrever que já é tarde, menina. Vá para a cama - costumavam dizer quando a viam perambulando pelos corredores com seu caderninho na mão.

Todos dormindo, e ao fundo nem mesmo o confortante ruído dos sapos e grilos dos contos infantis. Apenas o silêncio. Aquele silêncio lento do Tom. Aquele silêncio mudo da agonia de retorcer-se na cama, não dormir, não acordar, ficar na eminência de cada um, vagado entre o limbo dos sonhos e o mundo real. Foi então que num instantâneo abrir de olhos ela 
saltou para fora da cama, ganhou a sala, caminhou, caminhou e caminhou até a porta do quarto do hóspede. Entrou, examinou-o a dormir, cheirou seus pertences e controlou a vontade de urinar naquele chão. Também controlou a vontade de escrever no seu caderninho. Sentou-se suavemente e apenas o observou a dormir. E enquanto o fazia, não pensava em nada. Simplesmente, felinamente, o observava. Aos primeiros ruídos matinais, ela salta a janela do quarto dele e maciamente retorna ao seu.

Inexplicavelmente virou rotina. Acordava no meio da noite e o vigiava a dormir. Em uma dessas noites, olho-o tão de perto que não conseguiu controlar o beijo, que espantosamente foi retribuído. E a retribuição foi mútua e mútua e mútua... Ao primeiro raiar de sol, ela volta para a sua própria cama. Incrédula, fascinada, temerosa. Com pesadas batidas no peito. Acontecera. Finalmente acontecera com ela. Mas era disso que tanto se falava por aî? Nada demais. Nada demais. E foi por esse "nada demais" que ela continuou a visitar-lhe o quarto por mais...uma semana? Talvez dez dias. Dez dias. Era um sentimento sem rosto, sem forma e sem nome, vivido em dias etéreos, eternos, etílicos.

Mas o curioso (se não estranho) foi que a ardência noturna não se transformou sequer em curiosidade diurna. Os dois continuavam sem se ver, sem se falar. Principalmente: sem se falar. Nem nos raros e inevitáveis esbarros pela casa, nem nas puladas noturnas de janela. O que será que ele pensava sobre tudo isso? Ela, certamente nada. O fulgor e o esplendor que lhe invadia não deixavam espaço para pensamentos. Ela queria sentir, e só o sentir lhe bastava, e o pensar era demais abstrato para se sentir.

Um dia ele partiu. Acordou cedo e partiu. Ninguém havia comentado nada. Estranho...bem estranho. Agora as noites eram vazias, insolúveis. Seria preciso preenchê-las. Mas o que podia ser feito? Quase nada podia ser feito. Nada mais preencheria aquelas noites. Talvez agora o pensar a fizesse companhia. Se não o pensar, certamente o escrever. Folhas e folhas eram vorazmente preenchidas, e as noites continuavam vazias. Vazias como todas as noites antes dele. Vazias como tantas outras que ainda viriam. Vazias como agora ela se tornara e só depois, bem depois compreenderia. Vazias. 